\title{
ANALISIS KOMPARATIF PREFERENSI KONSUMEN DALAM BELANJA ONLINE
}

\author{
Stephanie Parengkuan ${ }^{1}$, Nina Nurhasanah ${ }^{2}$ \\ Fakultas Ekonomi dan Bisnis Universitas Esa Unggul \\ Jalan Arjuna Utara No 9 Kebon Jeruk Jakarta 11510 \\ nina.nurhasanah@esaunggul.ac.id
}

\begin{abstract}
Consumers have become a demanding target and an important factor to running fashion business. Fashion is accepted by the consumers and influences their behavior in many ways to buy a new product. Shopping is an activity that certainly done because of need or simply to fulfill a desire. The aim of this study was to analyze consumer preferences in online shopping between Tokopedia and Shopee based on price factor, website quality, product diversity and convenience. This research was conducted by quantitative method, which uses primary data obtained through questionnaires and uses Independent Sample t-test as an analysis tool. Analysis and discussion of this study found that there were significant differences between Tokopedia and Shopee as measured by the price and diversity of products, and there was no significant difference measured from the factors of website quality and convenience. From these results also showed the average consumer preference is more dominant on Tokopedia than Shopee in terms of price, website quality and product diversity, while Shopee has a way of comfort greater than Tokopedia. This means that consumers prefer to buy at Tokopedia stores rather than Shopee, but Shopee can survive by attracting consumers with its convenience. With the current study of research, the advice applied in this study is that consumers are attracted to the website that are profitable for them and ultimately lead them to shopping online.
\end{abstract}

Keywords: consumer preferences, online shopping, tokopedia and shopee

\begin{abstract}
Abstrak
Konsumen telah menjadi target utama dan faktor penting untuk menjalankan bisnis fashion. Fashion diterima oleh konsumen dan mempengaruhi perilaku mereka dalam banyak cara untuk membeli produk baru. Belanja adalah suatu kegiatan yang pasti dilakukan karena perlu atau hanya untuk memenuhi keinginan. Tujuan dari penelitian ini adalah untuk menganalisis preferensi konsumen dalam berbelanja online antara Tokopedia dan Shopee berdasarkan faktor harga, kualitas website, keragaman produk dan kenyamanan. Penelitian ini dilakukan dengan metode kuantitatif, yang menggunakan data primer yang diperoleh melalui kuesioner dan menggunakan Independent Sample $t$ test sebagai alat analisis. Analisis dan diskusi dari penelitian ini menemukan bahwa ada perbedaan yang signifikan antara Tokopedia dan Shopee yang diukur oleh harga dan keragaman produk, dan tidak terdapat perbedaan yang signifikan diukur dari faktor kualitas website dan kenyamanan. Dari hasil ini juga menunjukkan rata-rata preferensi konsumen lebih dominan pada Tokopedia dari pada Shopee dalam hal harga, kualitas website dan keragaman produk, Sedangkan Shopee memiliki cara kenyamanan lebih besar dari Tokopedia. Artinya konsumen lebih suka membeli di toko Tokopedia daripada Shopee, namun Shopee dapat bertahan dengan menarik konsumen dengan kenyamanannya. Dengan studi tentang penelitian saat ini, saran yang diterapkan dalam penelitian ini adalah bahwa konsumen tertarik terhadap situs penjualan yang menguntungkan bagi mereka dan akhirnya menyebabkan kecenderungan untuk berbelanja online.
\end{abstract}

Kata kunci: belanja online, preferensi konsumen, Tokopedia, Shopee

Pendahuluan

menyebar di dunia di akhir tahun 2019 dan Ketika wabah Virus Corona (Covid-19) mulai masuk ke Indonesia di awal Maret 2020, 
menyebabkan dampak yang signifikan tehadap penurunan perekonomian di negara-negara yang terdampak virus tersebut, termasuk Indonesia. Tetapi hal ini tidak sebanding dengan peningkatan jumlah belanja masyarakat melalui e-commerce. Atas alasan keamanan dan kesehatan, masyarakat lebih memilih untuk membeli kebutuhannya secara online, hal tersebut sejalan dengan pemberlakuan kebijakan pemerintah yaitu bekerja dari rumah atau work from home (WFH) dan perpanjangan masa belajar di rumah atau school from home (SFH). Beragam alasan masyarakat memilih $e-$ commerce yang mereka percaya untuk berbelanja, salah satunya kualitas website, harga, keragaman produk, kenyamanan, fitur, metode pembayaran, kecepatan berbelanja, respon penjual, promosi, kualitas produk, dsb.

Apabila suatu perusahaan akan mengeluarkan produk biasanya disesuaikan dengan kebutuhan dan keinginan konsumen. Dengan begitu maka produk tersebut dapat bersaing di pasaran, sehingga menjadikan konsumen memiliki banyak alternatif pilihan produk sebelum mengambil keputusan untuk membeli suatu produk yang ditawarkan di pasaran. Sejalan dengan teori yang diungkapkan Mullins dan Walker (2010) bahwa konsumen menjadikan harga sebagai indikator dari kualitas sebuah produk atau layanan. Motivasi konsumen dalam melakukan pembelian juga dipengaruhi oleh harga misalnya konsumen dalam membeli produk akan mencari produk yang sesuai dengan preferensinya, dengan pertimbangan mana produk yang paling ekonomis dan lebih mementingkan kuantitas. Sedangkan konsumen yang konsumtif lebih mengutamakan keinginan atau kepuasan tanpa mempertimbangkan kebutuhan atau manfaat serta harga barang tersebut. Kualitas website dibuat oleh perusahaan e-commerce dengan tujuan utama untuk meningkatkan penjualan dan menarik selera pembeli. Kualitas website yang dijelaskan Aladwani dan Palvia dalam (Bavarsad, 2013) menuju pada ukuran keunggulan website berdasarkan evaluasi dari pengguna layanan untuk memuaskan kebutuhan.

Selanjutnya keragaman produk juga menjadi daya tarik bagi konsumen terutama dapat memberikan alternatif pilihan yang bervariasi. Keragaman produk merupakan beragam produk yang sesuai dengan keinginan pembeli (Benson, 2007). Selain itu, kemudahan dalam mendapatkan informasi yang tepat, akurat dan terpercaya juga akan menambah kenyamanan konsumen dalam bertransaksi online dan membantu konsumen dalam mendapatkan pengalaman yang menyenangkan saat berbelanja online (Frank \& Kamis, 2012). Keyamanan dalam bertransaksi dan pengalaman yang menyenangkan juga dapat menjadi faktor mendorong seorang untuk membeli kembali produk atau layanan online. Studi Cuponation telah mengambil sampel 32 ecommerce dari Indonesian Ecommerce Association (idEA) dengan jumlah pengunjung bulanan sedikitnya 150.000 pengunjung dalam rentang Januari-Desember 2019.

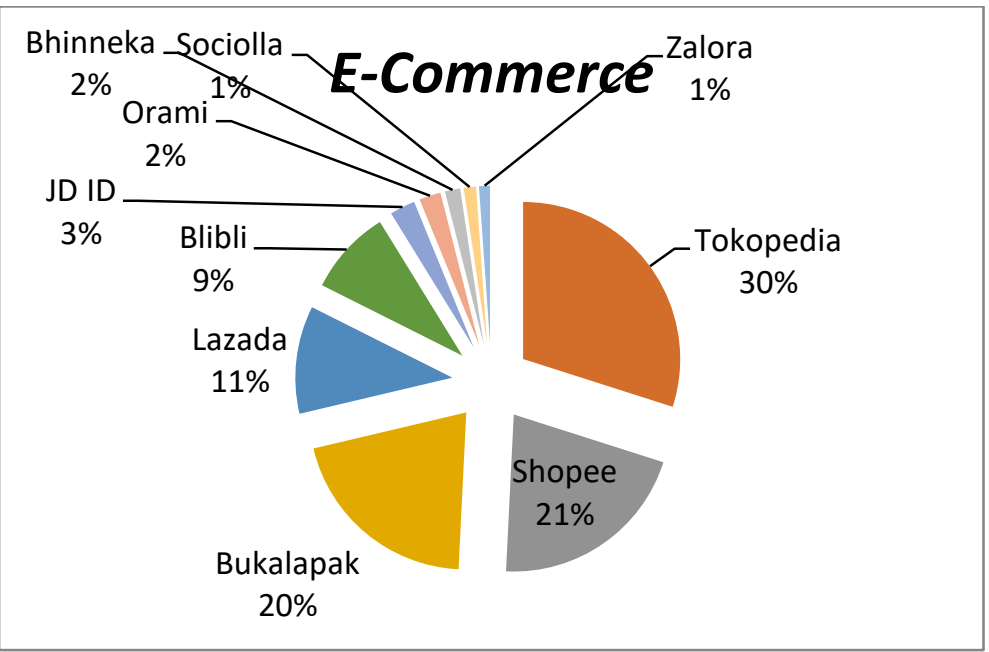

Gambar 1 E-Commerce di Indonesia

Sumber inews.id (22 Januari 2020) 
Berdasarkan gambar di atas, Shoppee (21\%) dan Tokopedia (30\%) adalah e-commerce terpopuler dan paling banyak digunakan oleh masyarakat Indonesia pada tahun 2019. Tokopedia memuncaki daftar market place terpopuler di Tanah Air. Sepanjang 2019, platform belanja online berlogo burung hantu itu dikunjungi sebanyak 1,2 miliar kali. Rinciannya, 863,1 juta lewat web mobile $(72,35 \%)$ dan 329,8 juta lewat desktop (27,65\%). Di peringkat kedua ada Shopee yang menggeser Bukalapak. Jumlah kunjungan Shopee pada tahun lalu mencapai 837,1 juta melampaui Bukalapak sebesar 823,5 juta (Fiansyah, 2020)

Banyak cara yang dilakukan oleh perusahaan market place untuk menarik minat pembeli dalam berbelanja melalui platform-nya, misalnya peningkatan kualitas website dan fitur yang canggih, persaingan harga dan kualitas barang, keragaman produk yang dijual dan kenyamanan dalam berbelanja, biasanya konsumen akan membandingkan (komparatif preferensi) lebih dari 1 market place sebelum melakukan belanja. Namun demikian, komparatif preferensi yang dilakukan konsumen sendiri yang menjadi keputusan akan berbelanja dimana.

\section{Preferensi Konsumen}

Sebelum

konsumen

membuat

keputusan, mereka akan melakukan beberapa proses evaluasi. Dalam proses itu, konsumen membandingkan preferensi di antara beberapa pilihan. Simamora (2013) menjelaskan preferensi konsumen merupakan pilihan atau minat individu untuk menyatakan suka atau tidak terhadap suatu produk.

Pengertian lain di sebutkan oleh Indarto, preferensi konsumen didefinisikan sebagai selera subjektif (individu), yang diukur atau dinilai dengan utilitas, dari berbagai barang. Preferensi konsumen adalah istilah umum yang berlakukan pada semua aspek produk dan layanan pemasaran. Ini tidak akan dikaitkan dengan istilah merek yang lebih spesifik daripada merek yang bersaing. Jika satu merek tidak tersedia, konsumen kemungkinan akan memilih merek lain untuk mengisi kekosongan (Indarto, 2011).

Menurut Rajpurohit dan Vasita, preferensi menunjukkan pilihan di antara opsi netral atau lebih dihargai yang tersedia. Konsumen sebagai faktor penting di pasar memiliki preferensi ketika mereka membuat keputusan. Preferensi konsumen ada ketika konsumen membuat beberapa perbandingan, evaluasi dan penilaian di antara berbagai pilihan yang tersedia, dan setelah itu membuat keputusan. Dan preferensi konsumen adalah hasil dari perilaku mereka yang mereka tunjukkan selama mencari, membeli, dan membuang produk. Ketika konsumen dihadapkan pada berbagai alternatif produk, mereka akan menerapkan preferensi. Preferensi konsumen adalah tentang rasa oleh individu. Ini adalah hasil ketika mereka mengevaluasi beberapa produk yang tersedia. Jadi preferensi konsumen adalah proses evaluasi berdasarkan pemilihan, minat, perbandingan, penilaian yang dilakukan konsumen sebelum memutuskan membeli/menggunakan suatu barang/jasa (Rejpurohit, 2011).

\section{Harga}

Harga menjadi salah satu elemen yang paling penting dalam menentukan pangsa pasar dan keuntungan suatu perusahaan. Kotler \& Amstrong mendefinisikan harga merupakan sejumlah uang-uang yang dikeluarkan untuk produk atau jasa, atau sejumlah nilai yang ditukarkan oleh konsumen untuk memperoleh manfaat atau kepemilikan atau penggunaan atas sebuah produk atau jasa Kotler (2016). Selain itu menurut Effendi M.Guntur (2010) harga adalah sejumlah uang yang ditagihkan atas suatu produk dan jasa atau jumlah dari nilai yang ditukarkan para pelanggan untuk memperoleh manfaat dari memiliki atau menggunakan suatu produk. Berdasarkan pendapat tersebut, penulis sampai pada pemahaman bahwa harga merupakan sejumlah uang yang ditukarkan untuk sebuah produk atau jasa. pemasar di dalam sebuah perusahaan harus benar-benar menetapkan harga yang tepat dan pantas bagi produk atau jasa yang ditawarkan karena menetapkan harga yang tepat merupakan kunci untuk menciptakan dan menangkap nilai pelanggan.

\section{Kualitas Website}

Kualitas website sendiri merupakan konsep penting untuk perdagangan secara online serta memiliki nilai tersendiri untuk 
konsumen. Kualitas website tidak hanya penting untuk memasarkan suatu produk dan jasa saja tetapi juga untuk memberikan informasi - informasi lainnya yang menarik bagi pelanggan, seperti (berita-berita terkini, produk terbaru, dan lain sebagainya). Hasil penelitian Gregg dan Walczak, menyatakan bahwa kualitas situs web (webqual) dapat meningkatkan penjualan dan intensitas transaksi penjualan sebesar $12 \%$ (Gregg, D. G., \& Walczak, 2010).

Untuk e-retailers, website digunakan sebagai sarana komunikasi dengan pelanggan, oleh sebab itu tampilan dan bentuk web site sangatlah penting. Menurut Shin (2013), kualitas website ini diartikan sebagai persepsi dari keseluruhan kualitas situs pusat perbelanjaan internet yang sesuai sudut pandang pelanggan. Sedangkan menurut Bavarsad (2013), website yang baik mempunyai kualitas operasional yang memungkinkan konsumen untuk melakukan kegiatan eshopping dengan lebih mudah dan efisien. Tampilan web site yang professional memberikan pelanggan rasa nyaman, maka dengan begitu pelanggan dapat lebih percaya dan nyaman dalam melakukan pembelian.

\section{Keragaman Produk}

Terdapat banyak hal yang harus diperhatikan oleh suatu perusahaan yaitu bagaimana membuat keputusan mengenai bauran produk yang dihasilkan pada saat ini maupun untuk masa mendatang. Bauran produk merupakan salah satu unsur yang harus diperhatikan oleh suatu bisnis. Menurut K. Kotler (2012:25), keragaman produk adalah tersedianya semua jenis produk mulai dari banyaknya jumlah, kesesuaian dengan selera dan keinginan serta ketersediaan produk yang ditawarkan untuk dimiliki, dipakai atau di konsumsi, oleh konsumen yang dihasilkan oleh suatu produsen.

Pendapat lain dari James F. Engels yang dikutip oleh Farli Liwe (2013) mengemukakan bahwa "Keragaman produk adalah kelengkapan produk yang menyangkut kedalaman, luas, dan kualitas produk yang ditawarkan, juga ketersediaan produk tersebut setiap saat di toko".

Keragaman produk yang dihasilkan suatu perusahaan mencakup Lebar (Width) yaitu mengacu pada berapa banyak lini produk yang berbeda yang dijual perusahaan, Panjang (Length) mengacu pada jumlah total produk dalam bauran tersebut, Kedalaman (Depth) mengacu pada banyaknya varian yang ditawarkan masing-masing produk pada lini tersebut dan konsistensi (Consistency) bauran produk, mengacu pada seberapa dekat hubungan dari berbagai lini produk pada penggunaan akhir. Keragaman produk, ketersediaan barang, kualitas produk yang ditawarkan oleh perusahaan e-commerce juga menjadi salah satu penentu apakah konsumen akan berbelanja melalui flatform-nya.

\section{Kenyamanan}

Kenyamanan diakui sebagai faktor yang mendorong preferensi konsumen untuk membeli secara online di rumah/kantor. Sejalan dengan pendapat tersebut, Sarkar dalam (Kamis \& Frank, 2012) menyebutkan bahwa pelanggan yang sudah merasakan kenikmatan dalam berbelanja online umumnya akan beralih dari berbelanja di toko konvensional ke toko online.

Berdasarkan Oxford Dictionary, convenience atau kenyamanan adalah "the state of being able to proceed with something without difficulty'. Adanya internet membuat konsumen lebih mudah dalam berbelanja. Konsumen tidak perlu menghadapi kemacetan, repot mencari parkir, dan berjalan dari satu toko ke toko lainnya. Konsumen hanya perlu berada di depan komputer mereka dan tersambung dengan internet.

Dengan adanya Covid-19, maka berbelanja melalui e-commerce menjadi kenyamanan bagi konsumen karena akan terhindar dari virus dan antrian yang panjang. Konsumen tidak perlu lagi keluar rumah, berkendaraan, mencari parkir bahkan bebas antrian.

\section{Perbandingan Preferensi Konsumen Berdasarkan Harga}

Harga produk memiliki peran aktif dalam dunia belanja online. Bila harga lebih murah dan terjangkau maka preferensi konsumen untuk membeli produk akan naik. Dari sudut pandang konsumen, harga sering kali digunakan sebagai indikator nilai bilamana harga tersebut dihubungkan dengan manfaat yang dirasakan atas suatu barang. Dengan 
demikian dapat disimpulkan bahwa tingkat harga tertentu, bila manfaat yang dirasakan konsumen meningkat, berarti nilainya akan meningkat juga (Tjiptono, 2014). Dalam penentuan nilai suatu barang, konsumen membandingkan kemampuan suatu barang dalam memenuhi kebutuhannya. Sehingga barang yang akan dibeli sesuai dengan nilai dan kebutuhan. Dari uraian di atas maka dapat ditarik satu hipotesis sebagai berikut:

H1: Diduga terdapat perbedaan preferensi konsumen dalam berbelanja online berdasarkan harga antara Shopee \& Tokopedia

\section{Perbandingan Preferensi Konsumen Berdasarkan Kualitas Website}

Kualitas dari suatu Website dalam sebuah situs online shop menjadi salah satu faktor yang dapat mempengaruhi preferensi pelanggan. Mengidentifikasikan dan mengklasifikasikan faktor-faktor website sangat perlu dilakukan termasuk pelaku- pelaku yang mungkin memberikan hasil dalam interaksi secara virtual. Wijayati (2015) menjelaskan secara operasional, produk berkualitas adalah produk yang memenuhi harapan konsumen. Produk harus memiliki tingkat kualitas terbaik karena produk dibuat untuk memenuhi selera konsumen atau memuaskan pemakainya. Dari uraian diatas maka dapat ditarik satu hipotesis sebagai berikut:

H2: Diduga terdapat perbedaan preferensi konsumen dalam berbelanja online berdasarkan kualitas website antara Shopee \& Tokopedia

\section{Perbandingan Preferensi Konsumen Berdasarkan Keragaman Produk}

Keragaman produk menjadi salah satu faktor kumpulan seluruh barang yang ditawarkan penjual tertentu kepada pembeli. Produk-produk yang dijual meliputi barang, property, jasa dan tempat. Dengan keragaman variasi produk yang ditampilkan atau dijual dapat membuat konsumen tertarik dan mempunyai niat untuk membeli walaupun tidak membutuhkannya. Chandra dan Adriana dalam Jasniko (2013), mengemukakan variasi produk cocok dipilih apabila produsen bermaksud memanfaatkan fleksibilitas produk sebagai strategi bersaing dengan para penjual. Hubungan antara keragaman produk dan preferensi konsumen dalam melakukan pembelian secara online sangat erat kaitannya pada kelangsungan perdagangan. Dari uraian diatas maka dapat ditarik satu hipotesis sebagai berikut:

H3: Diduga terdapat perbedaan preferensi konsumen dalam berbelanja online berdasarkan keragaman produk antara Shopee \& Tokopedia

\section{Perbandingan Preferensi Konsumen Berdasarkan Kenyamanan}

Kenyamanan dalam penelitian ini merujuk pada kenyamanan pengaksesan website dimanapun pada saat kapanpun serta kecepatan layanan informasi produk yang baik dari penjual. Kenyamanan pencarian produk (search convenience to product) merupakan kecepatan dan kemudahan yang dapat dirasakan oleh konsumen dalam menemukan produk yang diinginkan (Beauchamp, 2016). (Jiang, 2013), mengembangkan beberapa kategori untuk mengukur kenyamanan belanja online, yang terdiri dari akses ke aplikasi pencarian produk, evaluasi, transaksi, kepemilikan, dan pasca pembelian. Dari uraian diatas maka dapat ditarik satu hipotesis sebagai berikut:

H4: Diduga terdapat perbedaan preferensi konsumen dalam berbelanja online berdasarkan kenyamanan antara Shopee \& Tokopedia.

H5: Diduga tidak terdapat perbedaan preferensi konsumen dalam berbelanja online berdasarkan harga, kualitas website, keragaman produk dan kenyamanan.

Berdasarkan kerangka hipotesa di atas, dapat digambarkan model penelitian sebagai berikut:

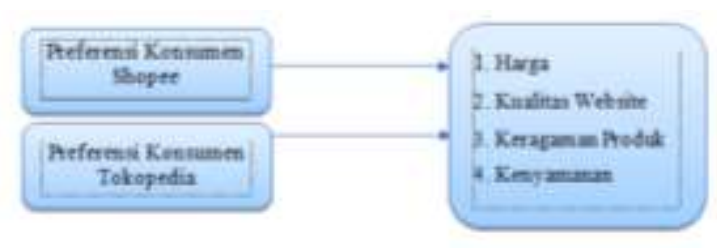

Gambar 2

Model Penelitian

\section{Metode Penelitian}

Penelitian ini menggunakan metode survey dengan alat berupa kuesioner yang disebarkan baik secara online maupun offline sebagai teknik pengumpulan data sebanyak satu 
kali. Sehingga, data yang didapatkan berupa data primer. Kuesioner menggunakan pengukuran skala likert dengan skala 1-5 (1 = sangat tidak setuju dan $5=$ sangat setuju). Penelitian ini menguji perbedaan preferensi konsumen dalam berbelanja online di Shopee dan Tokopedia ditinjau dari dimensi harga, kualitas website, keragaman produk dan kenyamanan.

\section{Populasi dan Sampel}

Dalam penelitian ini yang menjadi populasi adalah seluruh Masyarakat yang berada di DKI Jakarta. Jumlah populasi dalam penelitian ini tidak diketahui, namun karakteristik dari populasi tersebut bersifat homogen atau sama. Teknik pengambilan sampel yang digunakan pada penelitian ini adalah non probability sampling, yaitu teknik pengambilan sampel yang tidak memberi peluang atau kesempatan sama bagi setiap unsur atau anggota populasi untuk dipilih menjadi sampel. Metode yang digunakan adalah purposive sampling yaitu peneliti menggunakan pertimbangan sendiri secara sengaja dalam memilih anggota populasi yang dianggap dapat memberikan informasi yang diperlukan atau unit sampel yang sesuai dengan kriteria tertentu yang diinginkan peneliti yaitu konsumen yang belanja online melalui Shopee dan Tokopedia di DKI Jakarta (Sugiyono, 2010). Menurut Jumlah sampel minimal yang harus dipenuhi dalam penelitian ini didasarkan pada rumus Rao Purba (Kharis, 2011), jumlah sampel minimal ditentukan dengan rumus:

Dimana:

$\mathrm{n}=$ ukuran sampel

$\mathrm{Z}$ = tingkat keyakinan sampel yang dibutuhkan dalam penelitian (pada $a=5 \%$ atau derajat keyakinan ditentukan 95\% maka $Z=1,96) \mu=$ margin of error, tingkat kesalahan yang dapat ditolerir (ditentukan 5\%)

$$
\mathrm{n}=\frac{1,96^{2}}{4(0,1)^{2}}=96,04
$$

Berdasarkan rumus di atas dapat diambil sampel dari populasi yang besar sebanyak 100 orang responden. Pada prinsipnya tidak ada aturan yang pasti untuk menentukan presentase yang dianggap tepat dalam menentukan sampel, maka dalam hal ini peneliti mengambil sampel 100 orang responden yang cukup mewakili untuk diteliti, yaitu konsumen belanja online melalui Shopee dan Tokopedia di DKI Jakarta.

\section{Teknik Analisis Data}

Uji Validasi

Validitas yang digunakan dalam penelitian ini (content validity) menggambarkan kesesuaian sebuah pengukur data dengan apa yang akan diukur. Biasanya digunakan untuk menghitung korelasi antara setiap skor butir instrumen dengan skor total (Sugiyono, 2010). Dalam melakukan pengujian validitas, digunakan alat ukur berupa program komputer yaitu SPSS, dan jika alat ukur mempunyai korelasi yang signifikan antara skor item terhadap skor totalnya maka dikatakan alat skor tersebut adalah valid. Nilai signifikansi korelasi variabel total dengan masing-masing variabel pertanyaan dibawah nilai alpha 0,05, dapat disimpulkan bahwa hasil dari variabel tersebut valid (Trihendradi, 2013).

\section{Uji Reliabilitas}

Reliabilitas adalah alat untuk mengukur suatu kuesioner yang merupakan alat pengukuran konstruk atau variabel. Suatu kuesioner dikatakan reliabel atau handal jika jawaban seseorang, terhadap pertanyaan adalah konsisten atau stabil dari waktu ke waktu. Uji reliabilitas adalah tingkat kestabilan suatu alat pengukur dalam mengukur suatu gejala/kejadian. Semakin tinggi reliabilitas suatu alat pengukur, semakin stabil pula alat pengukur tersebut. Dalam melakukan perhitungan Alpha, digunakan alat bantu program komputer yaitu SPSS for Windows 21 dengan menggunakan model Alpha Cronbach. Sedangkan dalam pengambilan keputusan reliabilitas, suatu instrumen dikatakan reliabel jika nilai Cronbach Alpha lebih besar dari 0,6.

\section{Uji Normalitas}

Pengujian Normalitas menggunakan uji statistic, yaitu uji Shapiro-Wilk. Adapun kriteria pengujian adalah:

$\mathrm{Ha}=$ Data residual tidak berdistribusi normal

$\mathrm{Ho}=$ Data residual berdistribusi normal

Apabila nilai signifikansi uji Shapiro-Wilk adalah 
lebih kecil dari 0,05 maka Ha diterima, sehingga data residual tidak berdistribusi normal. Sebaliknya apabila nilai signifikansi Shapiro-Wilk adalah lebih besar dari 0,05 maka Ho diterima, sehingga data residual berdistribusi normal.

\section{Uji Beda T-Test (Independent Sample T- Test)}

Uji beda merupakan alat uji statistic yang dipergunakan untuk menguji perbedaan preferensi konsumen dalam berbelanja online pada Shopee dan Tokopedia. Jika data berdistribusi normal, maka alat uji yang dipergunakan adalah uji t. Uji parametik yang digunakan adalah uji peringkat tanda Independent Sampel T-Test. Uji ini digunakan untuk mengetahui signifikasi perbedaan preferensi konsumen dalam berbelanja online di Shopee dan Tokopedia, dengan membandingkan perbedaan masing-masing indikator (rasio). Uji beda t-test ini untuk mengevaluasi perbedaan antara sarana dua kelompok independen atau yang tidak terkait. Mengevaluasi apakah sarana untuk dua kelompok independen secara signifikan berbeda satu sama lain. Horn dalam (Rejpurohit, 2011) menyatakan uji beda t-test mengevaluasi perbedaan antara sarana dua kelompok independen atau tidak berpasangan. Uji sampel independen umumnya disebut sebagai desain antar kelompok, dan juga dapat digunakan untuk menganalisis kontrol dan kelompok eksperimental.

Uji t-test adalah tes hipotesis statistik di mana statistik tes mengikuti distribusi t peneliti, jika hipotesis null didukung. Ini paling umum diterapkan ketika statistik tes akan mengikuti distribusi normal jika nilai istilah penskalaan dalam statistik tes diketahui. Ketika jangka waktu penskalaan tidak diketahui dan digantikan oleh perkiraan berdasarkan data, statistik pengujian mengikuti distribusi $t$ peneliti. Uji-t ini digunakan untuk menganalisis preferensi konsumen dalam berbelanja online antara Tokopedia dan Shopee.

\section{Hasil dan Pembahasan}

Terdapat beberapa karakteristik responden dalam penelitian ini. Karakteristik responden yang dibahas dalam penelitian ini antara lain jenis kelamin, usia, latar belakang pendidikan, pekerjaan, pendapatan dan frekuensi belanja. 100 responden berasal dari pelanggan Tokopedia dan Shopee yang sudah berbelanja dan memiliki pengalaman di area perbelanjaan tersebut. Setiap karakteristik jenis kelamin, usia, latar belakang pendidikan, pekerjaan, pendapatan dan frekuensi kunjungan akan ditampilkan dalam beberapa grafik (lampiran). Berdasarkan jenis kelamin, dalam penelitian ini wanita unggul dengan $71 \%$ responden dan untuk pria $29 \%$ responden. Berdasarkan kategori usia antara 20-25 tahun adalah responden terbanyak, dengan 59\% responden. Berdasarkan latar belakang pendidikan, untuk responden gelar S1 dengan jumlah responden $46 \%$ memiliki persentase tertinggi Berdasarkan pekerjaan responden yang dikategorikan swasta adalah 54\% responden tertinggi. Mewakili pendapatan sekitar Rp. 2.500.000 sampai Rp. 5.000.000 adalah persentase tinggi. Berdasarkan frekuensi berbelanja ada $41 \%$ responden tertinggi dengan konsumen yang berbelanja di Tokopedia dan Shopee 4 sampai 6 kali dalam 6 bulan terakhir.

\section{Grup Statistik Data Beda T- Test}

Hasil statistik grup data menunjukkan bahwa rata-rata harga untuk Tokopedia adalah 19,28 sedangkan rata-rata harga untuk Shopee adalah 17,92, dalam hal kualitas website untuk Tokopedia adalah 19,06 dan rata-rata kualitas website untuk toko Shopee adalah 18,14.

Sementara rata-rata keragaman produk untuk Tokopedia adalah 19,28 sedangkan rata-rata keragaman produk untuk Shopee adalah 17,42. Dan untuk rata-rata kenyaman untuk Tokopedia adalah 18.02 dan rata-rata kenyamanan Shopee adalah 18.90. Dari hasil ini menunjukkan rata-rata Tokopedia pada harga, kualitas website, dan keragaman produk lebih besar dari Shopee. Sedangkan Shopee memiliki cara kenyamanan lebih besar dari Tokopedia. Artinya konsumen lebih suka membeli di toko Tokopedia daripada Shopee, namun Shopee dapat bertahan dengan menarik konsumen dengan kenyamanannya.

\section{Uji Beda T-Test (Independent Sample T- Test)}

Uji beda t-test dilakukan untuk menguji perbedaan signifikan antara konsumen 
Tokopedia dan Shopee dalam hal harga, kualitas website, keragaman produk dan kenyaman. Kriteria uji beda t-test adalah sebagai berikut:

- Sig. (2-tailed) $<0,05$ berarti $\mathrm{H}_{0}$ ditolak dan $\mathrm{H}_{a}$ diterima dan itu juga berarti bahwa ada perbedaan yang signifikan antara kedua kelompok itu

- Sig. (2-tailed) $>0,05$ berarti $\mathrm{H}_{0}$ diterima dan $\mathrm{H}_{\mathrm{a}}$ ditolak dan itu juga berarti bahwa tidak ada perbedaan yang signifikan antara kedua kelompok itu

Hasil menunjukkan bahwa sig. (2-tailed) $<0,05$ pada harga di Tokopedia dan Shopee adalah 0,017 . Ini berarti $\mathrm{H}_{0}$ ditolak dan $\mathrm{H}_{\mathrm{a}}$ diterima dan itu juga berarti bahwa ada perbedaan antara Tokopedia dan Shopee yang diukur dengan harga dalam situs penjualannya. Dengan kata lain, menurut konsumen Tokopedia dan Shopee memiliki nilai harga yang berbeda pada tiap produk yang dijual. Hasil menemukan bahwa sig. (2-tailed) $>0,05$ pada kualitas website adalah 0,130 di Tokopedia dan Shopee. Ini berarti $\mathrm{H}_{0}$ diterima dan $\mathrm{H}_{\mathrm{a}}$ ditolak dan itu juga berarti bahwa tidak ada perbedaan antara Tokopedia dan Shopee yang diukur dengan kualitas website dalam aplikasi. Terbukti bahwa dalam aplikasi Tokopedia dan Shopee konsumen dapat mengakses serta membeli produk yang diinginkan dengan baik dan tepat. Hal ini berarti Tokopedia dan Shopee menjalankan metode website yang sama dengan kemudahan dan kelebihan design masing-masing.

Hasil ketiga menemukan bahwa Sig. (2tailed) $<0,05$ pada variabel keragaman produk dengan angka 0,003 di Tokopedia dan Shopee. Ini berarti $\mathrm{H}_{0}$ ditolak dan $\mathrm{H}_{a}$ diterima dan itu juga berarti bahwa ada perbedaan terkait keragaman produk antara Tokopedia dan Shopee dalam situs penjualannya. Dengan demikian, dalam banyaknya kategori produk dan variasi penjualan yang tersedia pada Tokopedia dan Shopee konsumen melihat perbedaan dalamnya. Jika dilihat bahwa jenisjenis produk dan kelengkapan yang ditampilkan dari kedua situs penjualan ini juga memiliki metode masing-masing sehingga terdapat produk, promosi, diskon dan gratis biaya pengiriman yang hanya di Shopee saja dan tidak ada pada Tokopedia, dan begitu juga sebaliknya.
Berdasarkan hasil keempat menemukan bahwa Sig. (2-tailed) $>0,05$ pada variabel kenyaman nilai 0,198 di Tokopedia dan Shopee. Ini berarti juga $\mathrm{H}_{0}$ diterima dan $\mathrm{H}_{a}$ ditolak dan itu juga berarti bahwa tidak ada perbedaan terkait kenyamanan antara Tokopedia dan Shopee dalam berbelanja online. Pasalnya, berdasarkan pendapat responden, tidak ada perbedaan tingkat kemudahan proses belanja, kecepatan pengiriman, respon layanan dan tingkat kepercayaan akun penjual yang diperlakukan dan ditunjukkan Tokopedia dan Shopee.

Revolusi di sektor fashion telah meningkat dan membawa pergeseran paradigma dalam fungsi bisnis. Dengan transformasi dalam teknologi informasi, aksesibilitas internet yang mudah, peningkatan dan andal toko fisik membuat pelanggan memiliki banyak pilihan untuk membeli produk terutama untuk produk pangan. Telah menjadi penting untuk menilai preferensi yang mempengaruhi konsumen saat mereka berbelanja. Dengan meningkatnya adopsi visi iklan internet, World Wide Web menjadi platform iklan standar secara bertahap. Web ini menawarkan dunia iklan bisnis dengan alat media yang kaya, seri interaktif, dan jangkauan global. Sejauh ini, komunikasi periklanan online menawarkan banyak peluang untuk meningkatkan kecakapan perilaku pembelian dan meningkatkan ketersediaan material produk atau informasi layanan, memenuhi syarat evaluasi multi karakteristik langsung, dan mengurangi biaya pelanggan. Selain itu, dalam faktor pasar periklanan online seperti harga, kualitas website, keragaman produk dan kenyamanan konsumen penting dalam mempengaruhi konsumen hingga akhirnya ingin mengakses dan membeli. Namun, konsumen mungkin berurusan dengan tenaga penjual jarak jauh, mereka belum pernah bertemu dan produk yang tidak dapat disentuh dan dirasakan. Demikian juga, konsumen cenderung tidak mau melakukan bisnis hanya berdasarkan informasi yang diberikan oleh merchant di pasar karena beberapa informasi mungkin tidak dapat diandalkan. Teori pemasaran tradisional berlanjut pada dasarnya hubungan dengan konsep kepercayaan konsumen untuk membeli karena meningkatkan kualitas produk yang tinggi dengan perilaku oportunistik oleh 
penjual.

Itu dibuktikan dengan perhitungan pada uji beda t-test yang menunjukkan bahwa ada perbedaan antara Tokopedia dan Shopee yang diukur dengan harga dalam situs penjualan. Dengan melihat hasil nilai rata-rata harga di Tokopedia lebih tinggi dari Shopee. Hal itu menandakan bahwa, efektivitas harga di situs Tokopedia lebih dipengaruhi oleh konsumen, ketimbang Shopee. Temuan ini mengungkapkan bahwa efektivitas nilai jual di Shopee tidak mempengaruhi pelanggan secara merata. Namun, ini bukan merupakan hasil yang pasti, karena pelanggan Tokopedia dan Shopee tidak hanya 100 responden dalam penelitian ini. Sejalan dengan itu diharapkan situs penjualan Shopee dapat lebih memperhatikan nilai yang sesuai dengan kualitas produk yang dijual dan meningkat nilai produk yang dihasilkan. Dalam penelitian ini juga terdapat hasil yang menunjukkan bahwa tidak ada perbedaan antara Tokopedia dan Shopee yang diukur dengan kualitas website. Artinya kualitas design serta tampilan dan informasi baik Tokopedia maupun Shopee masih memiliki hal yang sama atau tidak jauh berbeda atau terpengaruh secara merata. Pasalnya, kedua toko tersebut memiliki keterangan informasi serta tampilan yang sama untuk mengakses situs web dan juga aplikasi itu sendiri. Penting bagi perusahaan untuk menjaga keamanan dan privasi dengan aman, sehingga dapat membuat pelanggan merasa aman dan tidak berpikir dua kali untuk membeli dan memesan dari situs web. Dalam penelitian ini juga menunjukkan bahwa ada perbedaan terkait keragaman produk antara Tokopedia dan Shopee dalam situs berbelanja. Dengan melihat nilai rata-rata keragaman produk di Tokopedia lebih tinggi dari Shopee. Hal itu menandakan bahwa, keragaman produk di Tokopedia lebih dipengaruhi oleh konsumen, ketimbang toko Shopee. Temuan ini mengungkapkan bahwa keragaman produk di toko Shopee tidak mempengaruhi konsumen secara merata. Hasil penelitian menunjukkan tidak ada perbedaan terkait kenyamanan antara Tokopedia dan Shopee dalam situs berbelanja. Itu berarti kenyaman berbelanja oleh kedua toko ini masih memiliki hal yang sama atau tidak jauh berbeda. Mereka memiliki kesan yang baik untuk menjual merek dan produk mereka.

\section{Kesimpulan}

Berdasarkan analisis dan diskusi data, kesimpulan penelitian ini yaitu saat ini situs website yang baik adalah tugas vital pemasar yang telah dianggap sebagai alat dalam menciptakan citra mental positif perusahaan dan elemen penting untuk keberhasilan dalam berbelanja. website yang merupakan salah satu alat penting penjualan dan memainkan peran utama dalam menjalin komunikasi antara konsumen baik untuk digunakan sebagai media penjualan disaat pandemik seperti ini. Dengan studi tentang penelitian saat ini, saran yang diterapkan dalam penelitian ini adalah bahwa konsumen tertarik terhadap situs penjualan yang menguntungkan bagi mereka dan akhirnya menyebabkan kecenderungan untuk berbelanja online. Fokus utama dari penelitian ini adalah untuk mengetahui analisis komparatif preferensi konsumen dalam berbelanja online, berdasarkan harga, kualitas website, keragaman produk dan kenyamanan dan hasil penelitian ini menunjukkan bahwa harga dan keragaman produk memiliki dampak positif pada selera pembelian konsumen.

\section{Daftar Pustaka}

Batavio, A. B., Tripiawan, W., Industri, F. R., \& Telkom, U. (2017). Preferensi Konsumen Dalam Menggunakan Layanan Website Bukalapak Dengan Metode Conjoint Consumer Preferences in Using The Service of The Bukalapak Website Abstrak. 4(2), 2813-2820.

Bavarsad. (2013). Pengaruh Kualitas Website Pada Perceived Trust dan Niat Beli Ulang: Pengujian Efek Moderasi Variabel Website Brand dan Persepsi Nilai. Fakultas Ekonomi, Universitas Atma Jaya Yogyakarta Jalan, 1-15.

Beauchamp, \& P. (2016). Measuring consumer perceptions of online shopping convenience. Católica Porto Business School, Universidade Católica Portuguesa, March.

Benson. (2007). Preferensi Belanja Online Produk Pakaian.

Effendi M.Guntur. (2010). Harga dan Proses Terhadap Kepuasan Konsumen Kafe Instamie di Kota Bandung. 11(1), 15- 
24.

Farli Liwe. (2013). Pengaruh Harga, Keragaman Produk dan Merek Terhadap Keputusan Pembeliaan Produk Pada PT. Index Sukoharjo. 03(02), 533-540.

Fiansyah, R. (2020). 10 E-Commerce Terpopuler di Indonesia: Tokopedia Terdepan, Shopee Geser Bukalapak. INews.Id.

https://www.inews.id/finance/bisnis/10e-commerce-terpopuler-di-indonesiatokopedia-terdepan-shopee-geserbukalapak

Frank, K. \&. (2012). Pengaruh Kepercayaan dan Kenyamanan Berbelanja Online Terhadap Kepuasan Konsumen dan Niat Pembelian Ulang Zalora Indonesia (Studi Pada Mahasiswa Universitas Muhammadiyah Yogyakarta). 1-24.

Gregg, D. G., \& Walczak, S. (2010). The Relationship Between Website Quality, Trust And Price Premiums At Online Auctions. In Electronic Commerce Research, 10. https://link.springer.com/article/10.1007 /s10660-010-9044-2

Haricahyo, D. A. (2015). Analisis prediksi Minat Pelanggan Untuk Berbelanja Online Dengan Menggunakan Decomposed Theory of Planned Behavior.

Indarto. (2011). Analisis preferensi konsumen terhadap pembelian kopi instan white coffee di kecamatan kebumen kabupaten kebumen. Program Studi Agribisnis, Fakultas Pertanian, Universitas Sebelas Maret Surakarta, 14(2), 159-166.

Jasniko. (2013). Pengaruh Store Atmosphere, Keragaman Produk dan Harga Terhada p Keputusan Pembelian Konsumen Mirota Batik Yogyakarta.

Jiang. (2013). Analisis Pengaruh Kenyaman Layanan Online Terhadap Kepuasan Konsumen Mobile Commerce di Indonesia.

https://webcache.googleusercontent.co $\mathrm{m} /$ search?q=cache:7GUDyeTIuQkJ:https ://jimfeb.ub.ac.id/index.php/jimfeb/articl e/download/5634/4947+\&cd=1\&hl=en\& $\mathrm{ct}=\mathrm{clnk} \& \mathrm{gl}=\mathrm{id} \& \mathrm{client}=$ safari

Kereh, C. (2018). A Comparative Study of Consumer Preference of Coffee Shop
(Case Study: Starbucks and Excelso Coffee Shop).

Kharis. (2011). Analisis Pengaruh Kualitas Pelayanan, Harga Terhadap Loyalitas Pelanggan Pada Jasa Penerbangan PT. Sriwijaya Air Ambon. 15(2), 126-143.

Kotler, \& A. (2016). Analisis Faktor-Faktor Yang Mempengaruhi Loyalitas Nasabah Tabungan Bunaken Pada PT. Bank SulutGo Kantor Cabang Pembantu Ranotana (p. 324).

Kotler, \& K. (2012). Analisi Lokasi, Keragaman Produk, Kualitas Pelayanan dan Keputusan Pembelian Pada Usaha Kecil Rumah Makan Padang Di Kota Semarang. 25.

Manuahe, V. (2019). A Comparative Analysis of Consumer Retention Between Organized and Traditional Retailer in Manado.

Mullins \& Walker. (2010). Analisis Preferensi Konsumen Dalam Berbelanja Di Pasar Tradisional Dan Pasar Modern Di Kota Makassar. Journal of Chemical Information and Modeling, 53(9), 16891699.

Nuraini, D. (2019). Analisis Perbedaan Kepuasan Konsumen Terhadap. 15, 231-239.

Putri, C., Manajemen, P. S., Ekonomi, F., Bisnis, D. A. N., \& Surakarta, U. M. (2018). Pemasaran Online Dan Offline Pada.

Rejpurohit, V. (2011). a Comparative Analysis of Consumer Preferences Between Online and Offline Store (Case Study on Fashion Product). Jurnal EMBA: Jurnal Riset Ekonomi, Manajemen, Bisnis Dan Akuntansi, 5(3), 3282-3291. https://doi.org/10.35794/emba.v5i3.174 76

Saputra, W. N. (2017). Analisis Perbandingan Kualitas Pelayanan pada Warnet Jagonet Internet Center dan Warnet Dewa Net di Yogyakarta.

Shin, \& T. (2013). The Effect of Site Quality on Repurchase Intention in Internet Shopping Through Mediating Variables: The Case of University Students in South Korea. International Journal of Information Management, 33(3).

Simamora. (2013). Analisis Preferensi Konsumen Terhadap Keputusan Menggunakan Jasa Kursus Bahasa 
Inggris. 87.

Sugiyono. (2010). Metode Penelitian Kuantitatif dan Kualitatif dan R\&D.

Tjiptono. (2014). The Influence of The Academic Service Quality Toward Student (Study on Students of Business Administration of Telkom University) Mahasiswa (Studi pada Mahasiswa Administrasi Bisnis Universitas Telkom). 2(2), 125-133.

Trihendradi. (2013). Step by step SPSS 20: analisis data statistik. 20, 15195.

Wardhani, W., Berbelanja, K., Pribadi, P., Elektronik, P., Produk, K., \& Daring, B. (2017). Preferensi konsumen terhadap kategori produk yang dijual secara daring dan luring. Ready Star 2, 300304.

Wijayati. (2015). Analisis pengaruh kualitas produk terhadap keputusan pembelian melalui citra merek dan nilai pelanggan. 1-19. 